\title{
MDS2 Gene
}

National Cancer Institute

\section{Source}

National Cancer Institute. MDS2 Gene. NCI Thesaurus. Code C97615.

This gene plays a role in myelodysplastic syndrome. 